\title{
Respecting Democratic Roles
}

\author{
The Right Honourable Beverley McLachlin, P.C. Chief Justice of Canada*
}

Je suis très contente d'être ici avec vous ce soir ${ }^{1}$ et d'avoir été invitée à prononcer l'allocution d'ouverture devant cet important auditoire. Il n'arrive pas souvent que les trois pouvoirs de l'État - le législatif, l'exécutif et le judiciaire - se réunissent afin de discuter de leurs responsabilités et de leurs rapports mutuels.

There is a lot of confusion about the roles of these branches, to judge from current press. We hear the criticism that the executive is running the country at the expense of Parliament. We are also told that the courts are running the country, at the expense of Parliament and the executive. So where does the truth lie? Quel rôle appartient à chacune de ces institutions?

The answer is very clear and very simple, at least at first blush: the truth lies in the Constitution. Canada is a constitutional democracy. All powers, whether of Parliament, the executive or the courts, must be exercised in accordance with the Constitution. The Constitution provides and circumscribes the powers and role of each branch of government.

It follows that to ask whether the executive or the courts have too much power is to ask the wrong question. Too much power in relation to what? As always, when we ask the wrong question, we get a variety of conflicting answers in short, confusion. There is no hope of

* Madam Chief Justice McLachlin, B.A., M.A. (Philosophy), LL.B. This article is copyrighted and has been republished with permission from the Chief Justice of Canada.

These remarks were delivered on 22 November 2004, in Ottawa, at a joint presentation by the Canadian Bar Association and the Law Clerks of the Senate and the House of Commons, on Law and Parliament: Legislative, Executive, and Judiciary

- Three Branches of the Same Living Tree? agreement; rather there is merely the irresolvable clash of competing views.

If we are to make progress on the issue of what Parliament, the executive, and the courts should be doing, we must start with the right question: what does the Constitution say they should be doing? This is a question that we should be able to answer and get agreement on. Of course, that may not end the debate. Once we agree on what the respective roles of Parliament, the executive, and the courts are under the Constitution, we are in a position to consider whether those roles meet the needs of Canadian democracy as it stands at the beginning of the twenty-first century. If they do, then the debate ends. If the consensus is that they do not, then the debate moves to the next stage - should we amend our constitution to provide for a different allocation of power? The point is this. Short of amendment, the Constitution is the final word on the powers and roles of each branch of government. En conséquence, toute discussion de ces rôles commence par l'examen des responsabilités assignés à chacun par la Constitution.

In this presentation, I would like to discuss the roles of Parliament, the executive, and the courts under the Constitution. I will not try to say what, in the best of all possible worlds, they should be. I will argue that absent amendment of the Constitution, it is the responsibility of each branch of government to discharge, to the best of its resources and collective will and abilities, the duties the Constitution assigns to it, and to do this in an atmosphere of mutual respect. The Constitution requires each branch to act respectfully in relation to the other branches. So long as the other branches act within their powers, it is not useful, and indeed may be harmful, to 
suggest that what that branch of government is doing is "wrong" or "illegitimate." Only the Constitution can tell us what is legitimate.

In this spirit, I would like today to explore what the Canadian Constitution provides.

First, let me make a preliminary observation. The Canadian Constitution divides governance powers between the legislative, executive and judicial branches of government. Some, following in the footsteps of the American legal philosopher, Alexander Bickel, ${ }^{2}$ argue that only those elected to office can legitimately exercise power on behalf of the people governed. That argument has a powerful logical appeal. However, it founders on the rocks of reality. One searches in vain for a modern democracy which confines governance power exclusively to the elected. Certainly, the constitution of neither the United States nor Canada does so. The reality in Canada is that our constitution confers certain powers on unelected bodies, notably the courts. To start from the assumption that any exercise of governance power other than by elected officials is illegitimate is to ignore the reality of our democracy, as defined by our constitution.

Indeed, the thinking of Bickel, while it still attracts adherents, has been supplanted in many quarters by the view that to function well, other non-elected bodies, like courts and ombudsmen, must supplement core legislative institutions comprised of elected representatives. ${ }^{3}$ These institutions serve to support long-term values that may be compromised or difficult to support given the need of elected members to secure re-election and popular approval. Institutions like courts provide ancillary vehicles through which members of minority and disadvantaged groups can put forward alternate conceptions and seek accommodation of those interests within the larger polity. Moreover, they bring new ideas into democratic debate. All this encourages peaceful change as well as stability by accommodating

Alexander Bickel, The Least Dangerous Branch: The Supreme Court at the Bar of Politics, $2 \mathrm{~d}$ ed. (New Haven and London: Yale University Press, 1986).

P. Pettit, "Depoliticizing Democracy" (Paper presented to the $21^{\text {st }}$ Annual Internationale Vereinigung für Rechts- und Sozialphilosophie W orld Congress, Lund, Switzerland, August 2003) (2003) 7:1 Associations: Journal for Legal and Social Theory 22 . rather than repressing minority interests. In other words, this conception sees a healthy democracy not exclusively in terms of the will of the majority - as important as that is - but as a complex, polycentric enterprise. Such a conception, many scholars argue, is required to preserve stability and growth in today's complex, multicultural nations.

Against this background, let us return to the question of the constitutional roles of the legislative, executive and judicial branches, as expressed in our constitution.

First, the role of the legislative branch of government - in Canada, Parliament and the provincial legislatures. The Canadian Constitution, as expressed in the Constitution Acts of $1867^{4}$ and $1982,{ }^{5}$ confers pre-eminent power on these bodies. They alone possess the power to introduce and pass laws. The only limit on this power is that the laws must fall within their jurisdiction. Laws must fall under a head of power assigned to the legislating body by the BNA Act. In addition, they must comply with the Charter of Rights and Freedoms. ${ }^{6}$ Subject to these limits, Parliament and the provincial legislatures possess unlimited power. The Charter itself supports legislative preeminence. First, section 1 of the Charter permits laws to infringe the guaranteed rights if the government can show they are reasonably necessary in a free and democratic society. Second, section 33 permits Parliament or the legislatures to override court rulings of invalidity, and this on a simple majority vote. This applies to all Charter rights with the exception of linguistic rights, mobility rights, and basic democratic rights. Thus, the intention of the framers of the Canadian constitution is clear: Parliament and the legislatures are the pre-eminent players in our democracy. L'intention des auteurs de notre constitution est claire: le Parlement et les législatures provinciales sont les acteurs principaux dans notre démocratie.

Constitution Act, 1867 (U.K.), 30 \& 31 Vict., c. 3, reprinted in R.S.C. 1985, App. II, No. 5, online: CanLII < http://www.canlii. org/ca/const_en/const1867.html> [BNA Act].

Constitution Act, 1982, being Schedule B to the Canada Act 1982 (U.K.), 1982, c. 11, online: CanLII.<http://www.canlii. org/ca/const_en/const1982.html>

6 Canadian Charter of Rights and Freedoms, Part I of the Constitution Act, 1982, being Schedule B to the Canada Act 1982 (U.K.), 1982, c. 11, online: CanLII <http://www.canlii. org/ca/const_en/const1982.html\#I> [Charter]. 
The role of the executive, strictly put, is to carry out the directives of Parliament. However, the way in which the executive does this has changed drastically over the past century.

The executive branch of government consists of the Prime Minister and supporting ministers. In the British parliamentary system, ministers, representing departments of government, carried out, or executed, the commands of Parliament through civil servants. The ministers answered directly to Parliament for the performance of duties by their civil servants.

This basic model has been altered in two ways. First, there has been a great increase in delegated legislation - broad laws passed by Parliament or the legislatures that confer on the executive the right to make subsidiary rules, or regulations, by order in council. Such laws in effect transfer the legislature's legislative power to the executive branch. This transfer is said to be justified on grounds that it is required to govern effectively in the complex modern state.

The second change in the way the executive functions is the practice of delegating of executive functions to administrative tribunals. Work formerly done by civil servants under the direction of a minister, answerable to Parliament, is assigned to independent bodies set up for this purpose. This development is also justified on the ground that it is required for effective governance in the complex modern state. The result is that modern governments, federal and provincial, discharge the majority of their functions through a plethora of independent administrative tribunals like labour tribunals, pension boards, licencing boards, immigration appeal boards, and human rights tribunals. These boards and tribunals are not answerable to Parliament, as are the civil servants they replace. They are answerable only to courts, which may be asked to rule on whether particular rulings are within the statutory powers of a board or tribunal and conform to the principles of natural justice.

These two developments - the tendency to legislate by regulation and the devolution of executive authority to independent tribunals have effectively changed the scope of the power exercised by the legislative and executive branches of government. Ces développements se sont produits dans toutes les démocraties occidentales. Cette transformation des pouvoirs de l'exécutif et du législatif ne résulte pas d'amendements constitutionnels. Il est plutôt le fruit d'un transfert de facto de pouvoirs, rendu nécessaire par la complexité de la gouvernance moderne. The result is the modern regulatory state.

It is not for me to say whether the present allocation of power and responsibilities between the legislative branch and the executive branch is the best one to meet the needs of Canadian democracy today. This is a matter best left to our elected representatives. Nevertheless, in this debate, it is essential that each branch of government continue to acknowledge the commitment of the other to act in accordance with the Constitution.

This brings me to the third branch of democratic governance - the courts. Section 96 of the BNA Act establishes independent courts of inherent jurisdiction for each province of Canada. The courts are as much a part of our democracy as Parliament and the legislatures. L'Acte de l'Amérique du Nord britannique prévoyait aussi la possibilité de créer une cour d'appel générale pour le Canada, qui aurait compétence en dernier ressort à travers le pays. La cour à laquelle je siège a été créée par la loi sur la Cour suprême de $1875 .{ }^{8} \mathrm{Il}$ y a bien eu des tentatives en vue d'abolir la Cour dans les années 1870 et 1880, mais elles ont toutes échoué. Today there is a general agreement that the Supreme Court of Canada is part of our country's constitutional framework. ${ }^{9}$

What is the role of the courts? At its most basic, it is to decide legal disputes that citizens and the government ask them to decide. In deciding these disputes, the courts discharge a number of functions essential to democratic governance. First, they define the precise contours of the division of legislative powers between the federal and provincial governments. Second, they rule on legislation alleged to be unconstitutional for

BNA Act, supra note 4.

Supreme Court Act, R.S.C. 1985, c. S-26.

See Brian A. Crane \& Henry S. Brown, Supreme Court of Canada Practice (Scarborough, Carswell, 2000) at 2-3; and Peter W. Hogg, Constitutional Law of Canada, $4^{\text {th }}$ ed. looseleaf. (Scarborough, Carswell, 1997) at 8-2. 
violation of the Charter, and, in doing so, define the scope of constitutional rights and freedoms. Third, the courts exercise de facto supervision over the hosts of administrative tribunals created by Parliament and the legislatures.

The development of the modern regulatory state and the adoption of a constitutional bill of rights in the form of the Charter have increased the importance of these functions. The judicial branch of governance in modern democracies is now more significant and more visible than it was in nineteenth-century British parliamentary democracy. That cannot be denied. However, is this unconstitutional? Not, I would suggest, in any meaningful sense of the word. Parliament and the legislatures, in response to the perceived needs of the modern democracy we claim as ours, have created administrative tribunals and entrenched fundamental rights. This has increased the scope of matters on which the courts must adjudicate in discharging their traditional role. Nevertheless, the role remains essentially the same - to answer the legal questions that individuals and governments bring before it.

What, then, of the accusation that courts have gone beyond their proper role? The charge is made that activist judges - politicians cloaked in judicial robes - have gone beyond impartial judging to advocate for special causes and achieve particular political goals, and that this is undemocratic.

If it is true that judges are acting in this way, then they are indeed going beyond the role allotted to them by the Constitution. The judicial role is to resolve disputes and decide legal questions that others bring before the courts. It is not for judges to set the agendas for social change, or to impose their personal views on society. The role of judges is to support the rule of law, not the rule of judicial whim. Judges are human beings; but they must strive to judge impartially after considering the facts, the law, and the submissions of parties on all sides of the question. In our constitutional framework, the role of the politician and the role of the judge are very different. The political role is to initiate the debate and to vote according to judgment on what is best for the country. The judicial role, by contrast, is to resolve legal disputes formulated by others, impartially based on the facts and the law.
But is the charge true? Have judges become political actors? Are they encroaching on terrain that is not theirs under our constitution? In my opinion, the answer is no.

When we deconstruct the charge that the courts are overstepping their boundaries, we find that the claim can be understood in four different ways. First, the claim may be understood as saying that judges should never go against the will of elected representatives; que les choix faits par le Parlement et les assemblées législatives provinciales ne devraient jamais être écartés par des juges qui ne sont pas élus. This suggests that unelected judges should never undo the choices of Parliament and legislative assemblies. However, that, as I have argued, is plainly false under our constitution. The legislative and the executive branches strive in good faith to discharge their role in a manner that is consistent with our constitution. They seek to bring forward laws that do not impinge on the Charter, and to implement those laws without infringing fundamental rights. However, every now and then, these efforts are called into question, and someone must arbitrate the dispute. Under our constitution, that "someone" is the judicial branch. As I said earlier, the terms of our Constitution Acts call on judges to be the arbiters of constitutional validity, both in terms of division of powers and in terms of respect for fundamental rights. In performing that duty, judges must inevitably strike down legislation, and go against the will of elected representatives, whenever it fails to meet our constitutional standards.

Second, the charge of judicial activism may be understood as saying that judges are pursuing a particular political agenda, that they are allowing their political views to determine the outcome of cases before them. Very often, on this version, judges are seen as activist when one disagrees with their conclusions. Behind this criticism lies the assumption that the parameters of constitutional adjudication are so indeterminate that judges can bend them at will in the service of their own political objectives.

This version of the charge is also problematic, in my view. It is a serious matter to suggest that any branch of government is deliberately acting in 
a manner that is inconsistent with its constitutional role. Such a suggestion inevitably breeds cynicism, and undermines public confidence in all of our institutions of governance. It should not be made without convincing evidence of its truth. The evidence that judges in Canada pursue private political agendas is lacking. Judges are conscious of their special but limited role. Their judgments are replete with the need to defer to Parliament and the legislation on complex social issues. Should judges err and impose their personal views instead of the law, they are likely to be overturned on appeal. They may also be subject to internal censure. A visit to any of the thousands of courtrooms in this country - from the local magistrate courts to the Supreme Court of Canada - is unlikely to reveal judges acting like politicians. Rather, it will find them discussing the facts of the case and how the law applies to them. This is not some form of role-play. It is the morality of their role. An objective review of the thousands of judicial decisions reported each year reveals that judicial concern is focused not on plans to change society, but on interpreting and applying the law in a way that reflects legislative purpose.

The idea that judges are implementing their own political agenda may emerge from the fact that judges sometimes make decisions that have political implications. However, it is wrong to jump from this indisputable fact to the conclusion that judges are therefore assuming the political role. The law is the mechanism by which our society regulates itself. That is the business of politicians. But when the validity and interpretation of the laws is brought before the courts, that is the business of judges. The role of judges may take them into subject matter claimed by politicians. Nevertheless, it does not follow that the judges are acting as politicians; the judicial role remains distinct from the political.

Par conséquent, la deuxième version de l'accusation d'activisme judiciaire est sans fondement. Au contraire, la preuve indique que le contrôle constitutionnel n'est pas exercée totalement dans le flou ni constitue un écran derrière lequel les juges se cachent afin de poursuivre leurs propres priorités politiques.

The third version of the charge of judicial activism begins from the opposite assumption. It assumes that law is a totally determinate black and white activity. From there, it proceeds to purport that judges should apply the law, not make the law, or rewrite the law. This version of the charge of judicial activism rests on a mistaken perception of the nature of legal decision-making. The law does not apply itself, and the answers to constitutional questions are not obvious or preordained. If they were, we would not need judges. It follows that there is no clear demarcation between applying the law, interpreting the law, and making the law. The Charter is an abstract document, made up of general propositions, which must be given concrete application. To give it meaning, and to make it relevant to the lives of Canadians, judges must make choices among competing readings of our constitutional text, choices that can have long-term normative consequences. All of this is perfectly consistent with the traditional role of judges in our country.

Let me turn, finally, to the fourth version of the charge of judicial activism. This version suggests that judges are making decisions that should be made by elected representatives, who alone possess the necessary legitimacy for lawmaking and the institutional competence to weigh all the factors that must be considered in making difficult choices of public policy for Canadians. This is a subtler claim. Let me simply say that judges are sensitive to this concern, but have little choice in the matter.

Where a legal issue is properly before a court, not deciding is not an option. When a citizen claims that the state has violated his or her constitutional rights, the courts must referee the dispute. They do so with all necessary deference to legislative and executive expertise in weighing competing demands on the public purse, and competing perspectives on public policy. Lorsqu'ils statuent sur des questions sociales difficiles, les tribunaux font montre de déférence vis-à-vis des décisions du législateur. Judges recognize that:

in certain types of decisions there may be no obviously correct or obviously wrong solution, but a range of options each with its advantages and disadvantages. Governments act as they think proper 
within a range of reasonable alternatives, and the [Supreme] Court acknowledged in $M . v . H . \ldots$ that "the role of the legislature demands deference from the courts to those types of policy decisions that the legislature is best placed to make." 10

There are, however, limits. Deference does not mean simply rubber-stamping laws. If a law is unconstitutional, it is the duty of the courts to say so. In the words of my colleague Ian Binnie, in the recent decision of Newfoundland (Treasury Board) v. N.A.P.E.:

Whenever there are boundaries to the legal exercise of state power such boundaries have to be refereed. Canadian courts have undertaken this role in relation to the division of powers between Parliament and the provincial legislatures since Confederation. The boundary between an individual's protected right or freedom and state power must also be refereed. The framers of the Charter identified the courts as the referee. While I recognize that the separation of powers is an important constitutional principle, I believe that the s. 1 test set out in Oakes and the rest of our voluminous s. 1 jurisprudence already provides the proper framework in which to consider what the doctrine of separation of powers requires in particular situations, as indeed was the case here. To the extent [that some would invite] a greater level of deference to the will of the legislature, I believe acceptance of such an invitation would simply be inconsistent with the clear words of s. 1 and undermine the delicate balance the Charter was intended to achieve. ${ }^{11}$

In the end, when we examine what is really being said, the claim fails that judges are

10 Newfoundland and Labrador Association of Public and Private Employees v. Her Majesty The Queen in Right of Newfoundland (Treasury Board), [2004] 3 S.C.R. 381, 2004 SCC 66 at para. 83, online: CanLII <http://www.canlii.org/ca/cas/scc/2004/ $2004 \mathrm{scc} 66 . \mathrm{html}>$ [Newfoundland (Treasury Board) $v$. N.A.P.E.], citing M. v. H., [1999] 2 S.C.R. 3., online: CanLII $<$ http://www.canlii.org/ca/cas/scc/1999/1999scc28.html $>$.

11 Newfoundland (Treasury Board) v. N.A.P.E., ibid. at para. 116, citing R. v. Oakes, [1986] 1 S.C.R. 103, online: CanLII <www.canlii.org/ca/cas/scc/1986/1986scc7.html>. overstepping the proper constitutional boundaries of their role.

Let me return to where I began. In our constitutional democracy, each branch of government - legislative, executive and judicial has an important role to play in Canadian democracy. The role of each branch is different and complementary. The essence of each remains the same through the centuries. The legislative branch's role is to make laws. The executive branch's role is to enforce the law. Moreover, the judicial branch's role is to interpret the law and resolve disputes arising from the law. Each branch is a vital part of our democracy. Each branch must discharge its role with integrity and respect for the proper constitutional roles of the other branches. To do less is to diminish our democracy and imperil our future.

The Rt. Honourable Beverly McLachlin Chief Justice Supreme Court of Canada 